\section{Kontsevoy A.} Kontsevoi 5.

\title{
CALCULATIONS OF TWO-FLOW REGENERATION OF ACTIVATED METHYLDIETHANOLAMINE SOLUTION
}

The object of research is the stage of regeneration of the spent solution of purification of process gas from $\mathrm{CO}_{2}$ in the production of ammonia with a capacity of 1360-1500 t/day, in a two-section plate regenerator-recuperator. The calculations confirmed the possibility of replacing the monoethanolamine absorbent solution (MEA) with activated methyldiethanolamine solution (aMDEA) for a two-flow purification and regeneration scheme. One of the most problematic places is the lack of a mathematical model of two-flow regeneration of a new absorbent. During the study to determine the composition of the vapor-gas mixture used the method of material balance, which takes into account the temperature of the upper and lower parts of the regenerator and proposed numerical integration to calculate the number of plates of the regenerator.

An algorithm and a program of multivariate calculations have been developed and implemented in Excel, which provide for variation of concentration parameters over a vapor-gas mixture. Thermal calculations take into account the endothermic reactions of $\mathrm{CO}_{2}$ desorption, water evaporation and determine the specific heat consumption for solution regeneration. The decrease of specific heat consumption for regeneration of activated aMDEA solution from 4.4 to $3.11 \mathrm{MJ} / \mathrm{m}^{3} \mathrm{CO}_{2}$ was determined in comparison with $\mathrm{MEA}$ solution. The approximations of the equilibrium pressure of $\mathrm{CO}_{2}$ over the MDEA solution on the degree of carbonization of solution and the desorption temperature are approximated. The kinetic calculation of the regenerator established the number of plates equal to 14 when the number of 31 plates in a standard regenerator-recuperator. The calculated number of plates determines the reliable regeneration of the solution in one apparatus to the required degree of carbonization of coarsely (0.35) and finely regenerated (0.1) solutions. The reduction in the number of plates when using aMDEA is due to taking into account the properties of this solution, in particular, the difference in the equilibrium pressure of $\mathrm{CO}_{2}$ over aMDEA compared to MEA. The real possibility of using $40 \%$ aMDEA solution instead of $18 \%$ MEA solution on existing two-stream absorbers and regenerators without changing the technological scheme is established.

Keywords: process gas, carbon monoxide (IV), methyldiethanolamine, piperazine, two-section plate regenerator, numerical integration.

Received date: 10.08 .2020

Accepted date: 18.09 .2020

Published date: 31.12 .2020
Copyright (C) 2020, Kontsevoy A., Kontsevoi S. This is an open access article under the CC BY license (http://creativecommons.org/licenses/by/4.0)

\section{Introduction}

The regeneration of waste solutions obtained during the purification of process gas from carbon monoxide (IV) in the production of ammonia takes place in strippers (regenerators) - packed or disc-shaped. Physicochemical basis of regeneration is provided in [1]. Technological schemes for the regeneration of solutions of monoethanolamine (MEA) and potash, design features of the regenerators are considered in $[2,3]$. In works $[4,5]$, a comparative analysis of schemes and methods of purification from carbon monoxide (IV) is provided. The method of purification with the use of an activated solution of methyldiethanolamine (aMDEA) with a concentration of up to $50 \%$, activated with piperazine $\mathrm{C}_{4} \mathrm{H}_{10} \mathrm{~N}_{2}$ (PZ, diethylenediamine) with a concentration of up to $5 \%$, has become widespread [6, 7]. Examples of the design and industrial implementation of this method are a single-flow technological scheme of purification from $\mathrm{CO}_{2}$ with an ammonia capacity of 1,550 t/day [8] and amine purification with an ammonia capacity of 1,000 t/day [9]. Note that, unlike the purification stage, much less attention is paid to the aMDEA regeneration stage. Thus, the authors of [10] investigated the energy consumption for the regeneration of the mixed absorbent MEA/MDEA. A decrease in the energy of regeneration when using this solution in comparison with the MEA solution has been proven. In [11], the influence of the MDEA/PZ ratio on the energy consumption of regeneration of the flue gas cleaning solution of a coal-fired power plant was studied. In the study [12], the simulation of single-stream regeneration of the spent aMDEA solution in a tray desorber with an ammonia capacity of $600 \mathrm{t} /$ day was carried out. The results of modeling the two-flow regeneration of the MEA solution are given in [13].

Simulation of two-flow purification of process gas from $\mathrm{CO}_{2}$ with an activated solution of aMDEA is described by the authors of this work in [14]. The proposed material is a logical continuation of the specified work and reflects in-depth attention to the calculation aspects when introducing this method, especially for large-scale production. Therefore, the development and implementation of calculations of precisely two-stream solution regeneration is relevant. Thus, the object of research is the stage of regeneration of the spent solution for cleaning the process gas 
from $\mathrm{CO}_{2}$ in the production of ammonia with a capacity of 1360-1500 t/day in a two-section disc-type regeneratorrecuperator. And the aim of research is to substantiate the possibility of replacing an absorbent solution of monoethanolamine (MEA) with an activated solution of methyldiethanolamine (aMDEA) at multi-tonnage plants operating according to a two-line purification and regeneration scheme.

\section{Methods of research}

The algorithm of material and heat balances for regeneration of the MEA solution (USSR, RF, Ukraine) [13] was revised for appropriate calculations using aMDEA solution (USA) and implemented in the Excel environment. During the study, let's use our own method for calculating the composition of the vapor-gas mixture at the outlet of the upper and lower parts and numerical integration to calculate the number of regenerator plates. At the same time, it is taken into account that the twostream regeneration provides for the supply of the entire spent solution to the upper part of the regenerator with the parameters of the roughly regenerated solution. After that, half of the coarsely regenerated solution is fed to the lower part for regeneration with the parameters of the finely regenerated solution. The heat balance took into account the temperature parameters of the solutions, the vapor-gas mixture, and the endothermic reactions of $\mathrm{CO}_{2}$ desorption and water evaporation.

\section{Research results and discussion}

The output has the following parameters. The regenerator operates under a pressure of $P=1.7 \mathrm{~atm}$. The degree of carbonization of the AMDEA solution: at the exit from the stage of «fine» regeneration $X_{2 v}=0.1$; at the entrance to the stage of «rough» regeneration $X_{1 v}=0.67$; at the output $-X_{1 n}=0.35$. Gas temperature at the outlet of the separator: $t=40^{\circ} \mathrm{C}$; saturated vapor pressure at $t=40{ }^{\circ} \mathrm{C}: P_{2}^{*}=0.07245 \mathrm{~atm}$. Gas temperature at the outlet of the regenerator: $t=70^{\circ} \mathrm{C}$; saturated vapor pressure at $t=70{ }^{\circ} \mathrm{C}: P_{3}^{*}=0.3116 \mathrm{~atm}$.

Material balance. The composition of dry gas at the outlet of the separator (Table 1), into which it enters from the upper part of the regenerator, is determined according to the material balance of absorption [14]. All dissolving components, namely hydrogen, nitrogen, carbon monoxide (II), methane and argon, are desorbed during regeneration. The consumption of $\mathrm{CO}_{2}$ with the gas phase is determined by the stage of absorption, while part of this gas always remains in solution with the corresponding carbonation degree.

The following is an algorithm for calculations and tables of material balance at various points of the regeneration scheme for aMDEA solution.

Gas humidity at the outlet of the separator, fraction:

$$
N_{2}=\frac{P_{2}^{*}}{P}=\frac{V_{2}}{\left(V_{2}+V g\right)},
$$

where $N_{2}=0.07245 / 1.7=0.0426$, whence, in a certain sense, the consumption of dry gas $\left(V g=36,073.3 \mathrm{~m}^{3} / \mathrm{h}\right)$, let's determine the flow rate of water vapor at the outlet of the separator, $\mathrm{m}^{3} / \mathrm{h}$ :

$$
V_{2}=V g \cdot N_{2} /\left(1-N_{2}\right) ; \quad V_{2}=1,605.79 .
$$

The calculation results are shown in Table 2.

Table 1

Dry gas parameters after separator

\begin{tabular}{|c|c|c|c|c|}
\hline Component & $\mathrm{m}^{3} / \mathrm{h}$ & $\%$ vol. & $\mathrm{kg} / \mathrm{h}$ & $\%$ mass \\
\hline $\mathrm{H}_{2}$ & 268.39 & 0.744 & 23.89 & 0.034 \\
\hline $\mathrm{N}_{2}$ & 54.30 & 0.151 & 67.88 & 0.097 \\
\hline $\mathrm{CO}_{2}$ & $35,744.57$ & 99.089 & $70,202.34$ & 99.859 \\
\hline $\mathrm{CO}$ & 2.18 & 0.006 & 2.72 & 0.004 \\
\hline $\mathrm{Ar}$ & 1.70 & 0.005 & 3.04 & 0.004 \\
\hline $\mathrm{CH} \mathrm{H}_{4}$ & 2.12 & 0.006 & 1.52 & 0.002 \\
\hline $\mathrm{Total}$ & $36,073.26$ & 100 & $70,301.38$ & 100 \\
\hline
\end{tabular}

Table 2

Wet gas parameters after separator

\begin{tabular}{|c|c|c|c|c|}
\hline Component & $\mathrm{m}^{3} / \mathrm{h}$ & $\%$ vol. & $\mathrm{kg} / \mathrm{h}$ & $\%$ mass \\
\hline $\mathrm{H}_{2}$ & 268.39 & 0.718 & 23.89 & 0.033 \\
\hline $\mathrm{N}_{2}$ & 54.30 & 0.145 & 67.88 & 0.095 \\
\hline $\mathrm{CO}_{2}$ & $35,744.57$ & 95.685 & $70,202.34$ & 98.184 \\
\hline $\mathrm{CO}$ & 2.18 & 0.006 & 2.72 & 0.004 \\
\hline $\mathrm{A} \Gamma$ & 1.70 & 0.005 & 3.04 & 0.004 \\
\hline $\mathrm{CH} \mathrm{H}_{4}$ & 2.12 & 0.006 & 1.52 & 0.002 \\
\hline $\mathrm{H}_{2} \mathrm{O}$ & $1,605.79$ & 4.299 & $1,291.06$ & 1.806 \\
\hline $\mathrm{Total}$ & $37,356.37$ & 100 & $71,500.67$ & 100 \\
\hline
\end{tabular}

The water vapor removed from the separator must be compensated for by adding water to the regenerated solution.

Relative humidity of gas at the outlet of the regenerator, fraction:

$$
\begin{aligned}
& N_{3}=\frac{P_{3}^{*}}{P}=\frac{V_{3}}{\left(V_{3}+V g\right)}, \\
& N_{3}=0.3116 / 1.7=0.183,
\end{aligned}
$$

from where let's determine the flow rate of water vapor, $\mathrm{m}^{3} / \mathrm{h}$ :

$$
V_{3}=V g \cdot N_{3} /\left(1-N_{3}\right) ; \quad V_{3}=8,095.96
$$

The calculation results are presented in Table 3

Volume $\left(\mathrm{m}^{3} / \mathrm{h}\right.$ of water vapor) and mass $(\mathrm{kg} / \mathrm{h})$ of reflux for irrigation of the regenerator, respectively:

$$
\begin{aligned}
& V\left(\mathrm{H}_{2} \mathrm{O}\right)=V_{3}-V_{2} ; \\
& V\left(\mathrm{H}_{2} \mathrm{O}\right)=8,095.96-1,605.79=6,490.17 . \\
& M_{\text {reflux }}=m_{3}-m_{2} ; \\
& m_{\text {reflux }}=6,509.15-1,291.06=5,218.09 .
\end{aligned}
$$


Table 3

Wet gas parameters after regenerator

\begin{tabular}{|c|c|c|c|c|}
\hline Component & $\mathrm{m}^{3} / \mathrm{h}$ & $\%$ vol. & $\mathrm{kg} / \mathrm{h}$ & $\%$ mass \\
\hline $\mathrm{H}_{2}$ & 268.39 & 0.61 & 23.89 & 0.03 \\
\hline $\mathrm{N}_{2}$ & 54.30 & 0.12 & 67.88 & 0.09 \\
\hline $\mathrm{CD}_{2}$ & $35,744.57$ & 81.52 & $70,202.34$ & 91.51 \\
\hline $\mathrm{CO}$ & 2.18 & 0.005 & 2.72 & 0.004 \\
\hline $\mathrm{Ar}$ & 1.70 & 0.004 & 3.04 & 0.004 \\
\hline $\mathrm{CH}_{4}$ & 2.12 & 0.005 & 1.52 & 0.002 \\
\hline $\mathrm{H}_{2} \mathrm{O}$ & $8,095.96$ & 18.46 & $6,509.15$ & 8.48 \\
\hline Total & $43,846.53$ & 100 & $76,718.77$ & 100 \\
\hline
\end{tabular}

Heat balance. Heating of the solution is carried out due to the heat of the raw converted gas supplied to the boilers of the amDEA solution. The purpose of the calculation is to determine the heat $Q_{k g}$ coming from the converted gas for cleaning and must be cooled. Output data: consumption, $\mathrm{kg} / \mathrm{h}$, of the waste solution in the regenerator $m(\mathrm{aMDEA})_{s}=$ $=1,129,143.1$ [14]; the total consumption of two streams of solution from the regenerator $m(\mathrm{aMDEA})_{s}^{*}=1,059,306.96$ [14]. Heat capacity of aMDEA solution at the inlet and outlet: $C p_{\text {in }}=3.7 \mathrm{~kJ} /\left(\mathrm{kg} \cdot{ }^{\circ} \mathrm{C}\right)$; heat capacity of wet gas at the outlet of the regenerator: $C p_{3}=35 \mathrm{~kJ} /\left(\mathrm{kmol} \cdot{ }^{\circ} \mathrm{C}\right)$. The temperature of the spent aMDEA solution at the inlet to the regenerator: $t_{\text {in }}=68.61{ }^{\circ} \mathrm{C}$ [14]; temperature of the regenerated solutions of aMDEA and wet gas at the outlet of the regenerator, ${ }^{\circ} \mathrm{C}$ : $t_{\text {out }}=7$; temperature of condensate (reflux) at the outlet of the separator, ${ }^{\circ} \mathrm{C}: t_{4}=40$. Heat of desorption of $\mathrm{CO}_{2}, \mathrm{~kJ} / \mathrm{kg} \mathrm{CO}$ : $Q \mathrm{CO}_{2}=1,216$; heat of water evaporation in the regenerator, $\mathrm{kJ} / \mathrm{kg}: Q_{e v}=2,200$; heat loss, fraction: $W_{\text {loss }}=0.05$.

Heat balance equation:

$$
Q_{1}+Q_{4}+Q_{k g}=Q_{3}+Q_{5}+Q_{6}+Q_{\text {loss }}
$$

The main items of the arrival of the heat balance are: - heat introduced with the spent solution of aMDEA, $\mathrm{kJ} / \mathrm{h}$ :

$$
\begin{aligned}
& Q_{1}=m(a M D E A)_{s} \cdot t_{i n} \cdot C p_{i n} \\
& Q_{1}=1,129,143.1 \cdot 68.61 \cdot 3.7=286,640,879.9 \\
& - \text { heat of condensate }(\text { reflux }), \mathrm{kJ} / \mathrm{h}: \\
& Q_{4}=m_{\text {reflux }} \cdot t_{4} \cdot C p_{\text {water }} ; \\
& \mathrm{Q}_{4}=5,218.09 \cdot 40 \cdot 4.19=874,551.9
\end{aligned}
$$

where $C p_{\text {weater }}$ - the average heat capacity of water, $\mathrm{kJ} /\left(\mathrm{kg} \cdot{ }^{\circ} \mathrm{C}\right)$ : $C p_{\text {water }}=4.19$;

- heat introduced with the coolant (convertible gas), $\mathrm{kJ} / \mathrm{h}$ :

$$
\begin{aligned}
& Q_{k g}=\left(Q_{3}+Q_{5}+Q_{6}-\left(1-W_{\text {loss }}\right) \cdot Q_{1}-\right. \\
& \left.-\left(1-W_{\text {loss }}\right) \cdot Q_{4}\right) /\left(1-W_{\text {loss }}\right) .
\end{aligned}
$$

The main items of consumprion in the heat balance are: - heat, carried out by wet gas from the regenerator, $\mathrm{kJ} / \mathrm{h}$ :

$$
Q_{3}=\Sigma V \cdot t_{\text {out }} \cdot C p_{3} / 22.4,
$$

$Q_{3}=43,846.53 \cdot 70 \cdot 35 / 22.4=4,795,714.2$

- heat of reaction of desorption and evaporation, $\mathrm{kJ} / \mathrm{h}$ :

$Q_{5}=Q \mathrm{CO}_{2} \cdot m\left(\mathrm{CO}_{2}\right)_{\text {des }}+Q_{\text {evap }} \cdot m_{\text {vapor }}$,

$Q_{5}=1,216 \cdot 70,202.34+2,200 \cdot 6,509.15=99,686,175.44 ;$

- heat, removed by the regenerated solution of aMDEA (it is assumed that at the same temperature of fine and coarse regeneration solutions have the same heat capacity), $\mathrm{kJ} / \mathrm{h}$ :

$Q_{6}=m(0 \mathrm{MDEA})_{s}^{*} \cdot t_{\text {out }} \cdot C p_{\text {out }}$,

$Q_{6}=1,059,306.96 \cdot 70 \cdot 3.7=274,360,502.6$.

So, from equation (1) heat consumption for solution regeneration:

$Q_{k g}=111,279,521.5 \mathrm{~kJ} / \mathrm{h}$.

Heat loss to the environment, $\mathrm{kJ} / \mathrm{h}$ :

$Q_{\text {loss }}=\left(Q_{1}+Q_{4}+Q_{k g}\right) \cdot W_{\text {loss }}=19,939,073.6$.

Specific heat consumption per $1 \mathrm{~m}^{3} \mathrm{CO}_{2}, \mathrm{MJ} / \mathrm{m}^{3} \mathrm{CO}_{2}$ :

$Q_{s p}=Q_{k g} /\left(V\left(\mathrm{CO}_{2}\right)_{d e s} \cdot 1,000\right)$,

$Q_{s p}=111,279,521.5 /(35,744.57 \cdot 1,000)=3.11$.

Let's compare the data obtained with the specific heat consumption for solution regeneration with the literature data. According to [1], these costs for the regeneration of $18 \%$ MEA solution are 5.4 and $4.4 \mathrm{MJ} / \mathrm{m}^{3} \mathrm{CO}_{2}$ for a multi-stream scheme and a scheme with a regeneratorrecuperator, respectively. A decrease in the specific heat consumption for the regeneration of the activated aMDEA solution to $3.11 \mathrm{MJ} / \mathrm{m}^{3} \mathrm{CO}_{2}$ is expected, taking into account the properties of this solution, namely, the lower heat of desorption of $\mathrm{CO}_{2}$. The literature [7] indicates the possibility of reducing the unit flow rate to $3.78 \mathrm{MJ} / \mathrm{m}^{3} \mathrm{CO}_{2}$ when using aMDEA. According to the calculations, at $10 \%$ heat loss to the environment, this figure will be 3.73. Thus, the calculated data are of the same order of magnitude as the industrial data and indicate a real possibility of reducing the heat consumption for the two-flow regeneration of aMDEA in comparison with a similar regeneration process of the MEA solution. In addition, the analysis of the consumption of MEA and aMDEA solutions for the purification of process gas [14] showed a decrease in the consumption of the solution by $5.5 \%$ when using aMDEA, which will help to reduce the energy consumption for pumping. The developed algorithm and its implementation in Excel make it possible to carry out multivariate material and thermal calculations with varying concentration parameters for gas and solution, and their temperature.

Kinetic calculation of the upper part of the stripper (regenerator). The calculation of a plate stripper is reduced to determining the number of theoretical plates $N t$ by numerical integration of the expression:

$$
N t=\int d P /\left(P^{*}-P\right),
$$


where $P$ - working pressure of $\mathrm{CO}_{2}, \mathrm{kPa} ; P^{*}-$ equilibrium pressure, $\mathrm{CO}_{2}, \mathrm{kPa}$.

The data [7] of the values of the equilibrium partial pressure $P_{\mathrm{CO}_{2}}^{*}$ over the MDEA solution for the conditions of regeneration in the upper part of the apparatus were preliminary approximated, depending on the carbonization degree of the $X_{i}$ solution (in the range of $0.4-0.7$ ) and the temperature $T_{i}$ of desorption (in the range $323-393 \mathrm{~K}$ ), kPa:

$$
P_{\mathrm{CO}_{2}}^{*}=\exp (24.56+3.23 \cdot \ln X-5,990.67 / \mathrm{Ti}) \text {. }
$$

For processed 32 points, the average deviation of the calculated data from the reference data is $6.48 \%$.

It is taken into account that the equilibrium $\mathrm{CO}_{2}$ pressure over the activated aMDEA solution is lower than over the pure MDEA solution, and the dependence of the correction factor $K_{c o r}$ on the carbonization degree $X i$ and the temperature $T_{i}$ is obtained:

$$
\begin{aligned}
& K_{\text {cor }_{-} i}=6.0455-15.5865 \cdot X i+ \\
& +17.8558 \cdot X i^{2}-6.5993 \cdot X^{3}-6.0865 / T i .
\end{aligned}
$$

Thus, the equilibrium $\mathrm{CO}_{2}$ pressure over the activated aMDEA solution is, $\mathrm{kPa}$ :

$$
P i^{*}=\frac{P_{\mathrm{CO}_{2}}^{*}}{K_{\text {cor } \_i i}} .
$$

$\mathrm{CO}_{2}$ partial pressure in the upper part of the regenerator, $\mathrm{kPa}$ :

$$
\begin{aligned}
& P^{u}=P_{3} \cdot N\left(\mathrm{CO}_{2}\right) \cdot 101,325 / 1,000 / 100, \\
& P^{u}=1.7 \cdot 81.52 \cdot 101,325 / 1,000 / 100=140,42,
\end{aligned}
$$

where $\mathrm{N}\left(\mathrm{CO}_{2}\right)$ - the content of $\mathrm{CO}_{2}$ in the wet gas at the outlet from the regenerator (from the upper tray), \% vol., $N\left(\mathrm{CO}_{2}\right)=81.52$ (Table 3).

Conversion factor of equilibrium $\mathrm{CO}_{2}$ pressure to operating pressure for the entire range of calculations of the upper part of the regenerator:

$$
\begin{aligned}
& K_{\text {con }}=P^{u} / P^{u} p, \\
& K_{\text {con }}=140.42 / 189.73=0.74,
\end{aligned}
$$

where $P^{u} p=189.73$ - the calculated value of the equilibrium pressure of $\mathrm{CO}_{2}$ over the aMDEA solution according to equation (2) taking into account the correction factor $K_{c o r}$ according to equation (3) with the degree of carbonization $X_{1}=0.67$ and the temperature on the upper plate $341.61 \mathrm{~K}\left(68.61{ }^{\circ} \mathrm{C}\right)$. Let's note that it is for the upper tray that both the equilibrium and working partial pressures of $\mathrm{CO}_{2}$ over the amDEA solution are known. Thanks to the $K_{\text {con }}$ factor, the working partial pressure on other trays will be calculated. Of course, this is a definite approximation, but in the absence of data on the concentration of $\mathrm{CO}_{2}$ in the vapor-gas mixture along the height of the regenerator, just such a decision was made. Let's note that the design problems with the construction of the working line of the regeneration process determine a much smaller amount of information in comparison with the calculation of the absorption process.

Thus, the working pressure of $\mathrm{CO}_{2}$ above the solution at each step of integration is equal to:

$$
P_{i}=K_{c o n} \cdot P i^{*} .
$$

Integration step based on the working partial pressure of $\mathrm{CO}_{2}: d P_{i}=A B S\left(P_{i-1}-P_{i}\right)$.

The efficiency of the regenerator plate, depending on the degree of carbonation of the solution $X$, fraction:

$$
\eta_{i}=\frac{\left(7.48+57.49 \cdot X_{i}-31 \cdot X_{i}^{2}\right)}{100} .
$$

Taking into account the efficiency of the plate, the required number of plates per one integration step:

$$
N p r_{i}=N t_{i} / \eta_{i}
$$

Practical number of plates:

$$
N p r=\sum N p r_{i} .
$$

\begin{tabular}{|c|c|c|c|c|c|c|c|c|c|c|}
\hline No. & $X i$ & $T i$ & $P i_{\mathrm{CO}_{2}}^{*}$ & $K_{\text {COC_ } i}$ & $P_{i}^{*}$ & $P_{i}$ & $P_{i}^{*}-P_{i}$ & $d P_{i}$ & $\begin{array}{c}\text { Efficien- } \\
c y_{i}\end{array}$ & $N p r_{i}$ \\
\hline 0 & 0.67 & 341.61 & 306.49 & 1.62 & 189.73 & 140.42 & 49.31 & - & - & - \\
\hline 1 & 0.6636 & 342.43 & 310.01 & 1.62 & 191.46 & 141.71 & 49.76 & 1.28 & 0.32 & 0.081 \\
\hline 2 & 0.6572 & 343.26 & 313.40 & 1.62 & 193.07 & 142.89 & 50.17 & 1.19 & 0.32 & 0.074 \\
\hline 3 & 0.6508 & 344.09 & 316.67 & 1.63 & 194.54 & 143.98 & 50.56 & 1.09 & 0.32 & 0.068 \\
\hline 4 & 0.6444 & 344.92 & 319.81 & 1.63 & 195.88 & 144.97 & 50.90 & 0.99 & 0.32 & 0.061 \\
\hline 5 & 0.638 & 345.75 & 322.82 & 1.64 & 197.07 & 145.86 & 51.22 & 0.88 & 0.32 & 0.055 \\
\hline 45 & 0.382 & 378.861 & 300.787 & 2.313 & 130.033 & 96.240 & 33.793 & 1.991 & 0.249 & 0.236 \\
\hline 46 & 0.3756 & 379.689 & 298.356 & 2.345 & 127.255 & 94.184 & 33.071 & 2.056 & 0.247 & 0.252 \\
\hline 47 & 0.3692 & 380.516 & 295.662 & 2.377 & 124.395 & 92.067 & 32.328 & 2.117 & 0.245 & 0.267 \\
\hline 48 & 0.3628 & 381.344 & 292.705 & 2.410 & 121.459 & 89.894 & 31.565 & 2.173 & 0.243 & 0.284 \\
\hline 49 & 0.3564 & 382.172 & 289.483 & 2.444 & 118.452 & 87.668 & 30.783 & 2.226 & 0.240 & 0.301 \\
\hline 50 & 0.35 & 383.000 & 285.999 & 2.479 & 115.380 & 85.395 & 29.985 & 2.274 & 0.238 & 0.319 \\
\hline \multicolumn{10}{|c|}{ Practical number of plates } & 6.99 \\
\hline
\end{tabular}

The implementation of the algorithm is presented in Table 4. The number of practice plates is 6.99.

Lower part of the regenerator. In the lower part, a fine regeneration of the solution occurs due to the supply of heat to the boiler. The consumption of desorbed gases corresponds to their consumption during absorption at the stage of fine purification. According to the results of work [14], the composition of dry gas is given in Table 5 .
Determination of the number of plates in the upper part of the regenerator (fragment) 
Table 5

Consumption of dry gas absorbed at the stage of fine cleaning

\begin{tabular}{|c|c|c|c|c|}
\hline Component & $\mathrm{m}^{3} / \mathrm{h}$ & $\%$ vol. & $\mathrm{kg} / \mathrm{h}$ & $\%$ mass. \\
\hline $\mathrm{H}_{2}$ & 98.35 & 0.96 & 8.78 & 0.04 \\
\hline $\mathrm{N}_{2}$ & 19.97 & 0.19 & 24.96 & 0.12 \\
\hline $\mathrm{CO}_{2}$ & $10,172.11$ & 98.83 & $19,980.93$ & 99.82 \\
\hline $\mathrm{CO}$ & 0.80 & 0.01 & 1.00 & 0.005 \\
\hline $\mathrm{Ar}$ & 0.62 & 0.01 & 1.12 & 0.01 \\
\hline $\mathrm{CH} \mathrm{H}_{4}$ & 0.78 & 0.01 & 0.56 & 0.003 \\
\hline Total & $10,292.63$ & 100 & $20,017.34$ & 100 \\
\hline
\end{tabular}

The temperature of the vapor-gas mixture at the outlet of the lower part of the regenerator is $110^{\circ} \mathrm{C}$, the saturated vapor pressure is $1.4326 \mathrm{~atm}$. Outlet gas humidity, fraction:

$$
N_{4}=\frac{P_{4}^{*}}{P}=\frac{V_{4}}{\left(V_{4}+V g\right)},
$$

where $N_{4}=1.4326 / 1.7=0.842706$, whence, in a certain sense, the consumption of dry gas $\left(\mathrm{Vg}=10,292.63 \mathrm{~m}^{3} / \mathrm{h}\right)$, let's determine the flow rate of water vapor at the outlet of the separator, $\mathrm{m}^{3} / \mathrm{h}$ :

$$
V_{4}=V g \cdot \mathrm{N}_{4} /\left(1-N_{4}\right), \quad V_{4}=55,142.93 \text {. }
$$

The calculation results are shown in Table 6 .

Partial working pressure of $\mathrm{CO}_{2}$ at the outlet from the lower part of the regenerator, $\mathrm{kPa}$ :

$$
\begin{aligned}
& P^{l}=P_{3} \cdot N\left(\mathrm{CO}_{2}\right) \cdot 101,325 / 1,000 / 100, \\
& P^{l}=1,7 \cdot 15,55 \cdot 101,325 / 1,000 / 100=27,22,
\end{aligned}
$$

where $N\left(\mathrm{CO}_{2}\right)-\mathrm{CO}_{2}$ content in wet gas, \% vol., $N\left(\mathrm{CO}_{2}\right)=$ $=15.55$ (Table 6 ). The tabular data [7] of the values of the equilibrium partial pressure $P_{\mathrm{CO}_{2}}^{*}$ above the MDEA solution for the regeneration conditions in the lower part of the apparatus, depending on the degree of carbonization of the solution $X i$ (in the range 0.1-0.35) and the temperature $T_{i}$ of desorption (in the range $373-393 \mathrm{~K}$ ), $\mathrm{kPa}$ :

$$
\begin{aligned}
& P i_{\mathrm{CO}_{2}}^{*}= \\
& =\exp \left(24.47+2.68 \cdot \ln X i-\frac{6,524.41}{T}\right) .(7)
\end{aligned}
$$

For the processed 12 points, the average deviation of the calculated data from the tabulated data is $5.38 \%$.

It is taken into account that the equilibrium $\mathrm{CO}_{2}$ pressure over the activated aMDEA solution is lower than over the pure MDEA solution, and the dependence of the correction factor $K_{\text {corr }}$ on the carbonization degree $X i$ is obtained:

$$
\begin{aligned}
& K_{\text {cor }{ }_{-}{ }}=8.077-37.195 \cdot X i+ \\
& +87.957 \cdot X i^{2}-79.555 \cdot X i^{3}
\end{aligned}
$$

Thus, the equilibrium $\mathrm{CO}_{2}$ pressure over the activated aMDEA solution is, $\mathrm{kPa}$ :

$$
P i^{*}=\frac{P i_{\mathrm{CO}_{2}}^{*}}{K_{\text {cor_ii }}} .
$$

Conversion factor of equilibrium $\mathrm{CO}_{2}$ pressure to operating pressure for the entire range of calculations of the lower part of the regenerator:

$$
\begin{aligned}
& K_{\text {cor }}=P^{l} / P i^{*}, \\
& K_{\text {cor }}=27.22 / 113.765=0.23926,
\end{aligned}
$$

where $P_{i}^{*}=113.765$ is the calculated value of the equilibrium pressure of $\mathrm{CO}_{2}$ over the aMDEA solution according to equation (7), taking into account the correction factor

\begin{tabular}{|c|c|c|c|c|c|c|c|c|c|c|}
\hline No. & $X i$ & $T i$ & $P i_{\mathrm{CO}_{2}}^{*}$ & $K_{\text {Cor_ } i}$ & $P_{i}^{*}$ & $P_{i}$ & $P_{i}^{*}-P_{i}$ & $d P_{i}$ & $\begin{array}{c}\text { Effi- } \\
\text { ciency }_{i}\end{array}$ & $N p r_{i}$ \\
\hline 0 & 0.35 & 383 & 275.590 & 2.422 & 113.765 & 27.220 & 86.545 & - & - & - \\
\hline 1 & 0.345 & 383.3 & 268.727 & 2.447 & 109.825 & 26.277 & 83.548 & 0.943 & 0.236 & 0.048 \\
\hline 2 & 0.34 & 383.6 & 261.883 & 2.472 & 105.957 & 25.352 & 80.606 & 0.925 & 0.234 & 0.049 \\
\hline 3 & 0.335 & 383.9 & 255.060 & 2.497 & 102.161 & 24.443 & 77.718 & 0.908 & 0.232 & 0.050 \\
\hline 4 & 0.33 & 384.2 & 248.261 & 2.522 & 98.435 & 23.552 & 74.883 & 0.892 & 0.231 & 0.052 \\
\hline 5 & 0.325 & 384.5 & 241.489 & 2.548 & 94.776 & 22.676 & 72.100 & 0.875 & 0.228 & 0.053 \\
\hline 45 & 0.125 & 396.5 & 31.200 & 4.646 & 6.715 & 1.607 & 5.108 & 0.192 & 0.141 & 0.265 \\
\hline 46 & 0.12 & 396.8 & 28.318 & 4.743 & 5.971 & 1.429 & 4.542 & 0.178 & 0.139 & 0.281 \\
\hline 47 & 0.115 & 397.1 & 25.582 & 4.842 & 5.284 & 1.264 & 4.020 & 0.164 & 0.137 & 0.299 \\
\hline 48 & 0.11 & 397.4 & 22.993 & 4.944 & 4.651 & 1.113 & 3.538 & 0.151 & 0.134 & 0.319 \\
\hline 49 & 0.105 & 397.7 & 20.552 & 5.049 & 4.071 & 0.974 & 3.097 & 0.139 & 0.131 & 0.340 \\
\hline 50 & 0.1 & 398 & 18.258 & 5.157 & 3.540 & 0.847 & 2.693 & 0.127 & 0.129 & 0.365 \\
\hline \multicolumn{10}{|c|}{ Practical number of plates } & 6.8 \\
\hline
\end{tabular}
$K_{\text {cor } i}$ according to equation (8) with the degree of carbonization $X_{1}=0.35$ and the temperature of the vapor-gas mixture at the outlet of the lower part $383 \mathrm{~K}\left(110{ }^{\circ} \mathrm{C}\right)-$ see the first line of Table 7 . The implementation of the calculation algorithm is presented in Table 7 .

Table 6

Wet gas flow rates at the exit from fine regeneration

\begin{tabular}{|c|c|c|c|c|}
\hline Component & $\mathrm{m}^{3} / \mathrm{h}$ & $\%$ vol. & $\mathrm{kg} / \mathrm{h}$ & $\%$ mass. \\
\hline $\mathrm{H}_{2}$ & 98.35 & 0.15 & 8.78 & 0.01 \\
\hline $\mathrm{N}_{2}$ & 19.97 & 0.03 & 24.96 & 0.04 \\
\hline $\mathrm{CO}_{2}$ & $10,172.11$ & 15.55 & $19,980.93$ & 31.06 \\
\hline $\mathrm{CO}$ & 0.80 & 0.001 & 1.00 & 0.002 \\
\hline $\mathrm{Ar}$ & 0.62 & 0.001 & 1.12 & 0.002 \\
\hline $\mathrm{CH} \mathrm{H}_{4}$ & 0.78 & 0.001 & 0.56 & 0.001 \\
\hline $\mathrm{H}_{2} \mathrm{O}$ & $55,142.93$ & 84.27 & $44,311.29$ & 68.88 \\
\hline $\mathrm{Total}$ & $65,435.56$ & 100.00 & $64,328.63$ & 100.00 \\
\hline
\end{tabular}

Table 7

Determination of the number of plates in the lower part of the regenerator (fragment) 
The number of practical plates is 6.8. The total number of trays in the regenerator is $\approx 14$. In industry, using an MEA solution, regenerator-recuperators operate, which have 31 trays ( 22 trays in the upper part and 9 trays in the bottom) [15]. For guaranteed quality of regeneration, 2 devices are used, which is confirmed by the materials of work [13]. Thus, the use of an activated aMDEA solution will allow one device to be turned off, which will have a significant economic effect. In addition, the loss of this absorbent at the regeneration stage is less than that of MEA due to the significantly higher boiling point of MDEA.

\section{Conclusions}

The analysis of heat balance calculations showed a decrease in the specific heat consumption for the regeneration of the MEA solution from $4.02 \mathrm{MJ} / \mathrm{m}^{3} \mathrm{CO}_{2}$ [13] to $3.11 \mathrm{MJ} / \mathrm{m}^{3} \mathrm{CO}_{2}$ when using aMDEA solution. Material calculations showed a method for determining the practical partial pressure of $\mathrm{CO}_{2}$ at the outlets of the upper and lower parts of the regenerator, which made it possible to obtain the parameters of the working line for calculating the number of plates. The number of regenerator trays is determined by numerical integration and is 14 trays, which makes it possible to recommend the use of only one regenerator out of two that are involved in production. Thus, the mathematical modeling of a two-section regenerator has confirmed the real possibility of replacing an $18 \%$ MEA solution with a $40 \%$ aMDEA solution. This should be implemented on existing equipment and will not require a change in the technological scheme.

\section{References}

1. Semenova, T. A.; Semenova, T. A. (Ed.) (1977). Ochistka tekhnologicheskikh gazov. Moscow: Khimiia, 488.

2. Weiland, R. H., Hatcher, N. A., Nava, J. L. (2010). Post-combustion $\mathrm{CO}_{2}$ Capture with Amino-Acid Salts: Optimized Gas Treating. Available at: https://www.protreat.com/files/publications/43/ Manuscript CO2 Capture with Amino Acids.pdf

3. Yankovskyi, M. A., Demydenko, I. M., Melnykov, B. I., Loboiko, O. Ya., Korona, H. M. (2004). Tekhnolohiia amiaku. Dnipropetrovsk, UDKhTU, 300.

4. Semenov, V. P.; Semenov, V. P. (Ed.) (1985). Proizvodstvo ammiaka. Moscow: Khimiia, 368.
5. Rufford, T. E., Smart, S., Watson, G. C. Y., Graham, B. F., Boxall, J., Diniz da Costa, J. C., May, E. F. (2012). The removal of $\mathrm{CO}_{2}$ and $\mathrm{N}_{2}$ from natural gas: A review of conventional and emerging process technologies. Journal of Petroleum Science and Engineering, 94-95, 123-154. doi: http://doi.org/10.1016/j.petrol.2012.06.016

6. Weiland, R. H., Hatcher, N. A., Nava, J. L. (2007). Post-combustion $\mathrm{CO}_{2}$ Capture with Amino-Acid Salts: Optimized Gas Treating. Inc. Clarita. Available at: https://www.protreat.com/files/publications/43/Manuscript_CO2_Capture_with_Amino_Acids.pdf

7. Vakk, E. G., Shuklin, G. V., Leites, I. L. (2011). Poluchenie tekhnologicheskogo gaza dlia proizvodstva ammiaka, metanola, vodoroda i vysshikh uglevodorodov. Teoreticheskie osnovy, tekhnologiia, katalizatory, oborudovanie, sistemy upravleniia. Moscow, 480.

8. Combs, G., McGuire, L. (2010). MDEA Based $\mathrm{CO}_{2}$ Removal System Process Simulation. Louisiana. Available at: http://www. chemengservices.com/tech71.html

9. Aminovaia ochistka. GazSerf. Available at: http://gazsurf.com/ru/ gazopererabotka/oborudovanie/modelnyj-ryad/item/aminovayaochistka

10. Li, X., Wang, S., Chen, C. (2013). Experimental Study of Energy Requirement of CO2 Desorption from Rich Solvent. Energy Procedia, 37, 1836-1843. doi: http://doi.org/10.1016/j.egypro.2013.06.063

11. Khan, B. A., Ullah, A., Saleem, M. W., Khan, A. N., Faiq, M., Haris, M. (2020). Energy Minimization in Piperazine Promoted MDEA-Based CO2 Capture Process. Sustainability, 12 (20), 8524. doi: http://doi.org/10.3390/su12208524

12. Kontsevoi, A. L., Lukianchuk, T. O., Kontsevoi, S. A. (2018) Modeliuvannia reheneratsii rozchynu metyldietanolaminu. Internauka, 16 (56), 32-36.

13. Kontsevoy, A., Kontsevoi, S. (2019). Modeling of two-flow regeneration of monoethanolamine solution. Visnyk Cherkaskogo Derzhavnogo Tekhnologichnogo Universytetu. Seriia: tekhnichni nauky, 4, 96-101. doi: http://doi.org/10.24025/2306-4412.4.2019.184512

14. Kontsevoy, A., Kontsevoi, S. (2020). Modeling of a two-flow gas purification from carbon oxides (IV) by methyldiethanolamine solution. Technology Audit and Production Reserves, 5 (3 (55)), 34-37. doi: http://doi.org/10.15587/2706-5448.2020.214440

15. Spravochnik azotchika: Fiziko-khimicheskie svoistva gazov $i$ zhidkostei. Proizvodstvo tekhnologicheskikh gazov. Ochistka tekhnologicheskikh gazov. Sintez ammiaka (1986). Moscow: Khimiia, 512.

Kontsevoy Andriy, PhD, Associate Professor, Department of Inorganic Technology, Water Purification and General Chemical Technology, National Technical University of Ukraine «Igor Sikorsky Kyiz Polytechnic Institute», Kyiv, Ukraine, e-mail: kontsev@xtf.kpi.ua, ORCID: http://orcid.org/0000-0002-1753-416X

Kontsevoi Sergii, PhD, Associate Professor, Department of Inorganic Technology, Water Purification and General Chemical Technology, National Technical University of Ukraine «Igor Sikorsky Kyiz Polytechnic Institute», Kyiv, Ukraine, e-mail: serkon157@ukr.net, ORCID: http://orcid.org/0000-0002-4523-2273 